\title{
Raking plates of the combination machine's subsoiler
}

\author{
Khayriddin Fayzullayev ${ }^{*}$, Dilmurod Irgashev, Sodiq Mustapakulov and Mokhichekhra \\ Begimkulova
}

Karshi Engineering Economic Institute, Karshi, Uzbekistan

\begin{abstract}
The purpose of the research is to justify the type of subsoiling plates of the machine for preparing the soil for sowing melon crops. The machine designed by the authors for the preparation of the soil for sowing melon crops under the tunnel film is equipped with deep loosening subsoilers of "paraplough" type with loosening plates. The scheme of subsoiler arrangement on the frame of the machine is shown. The basic principles and methods of classical mechanics, mathematical analysis, and statistics were used in this study. The scheme of subsoiler arrangement on the frame depending on their parameters has been theoretically justified. Experimental studies have established that using a subsoiler in the form of a rod and plate with a length of $12 \mathrm{~cm}$ and a height of $20 \mathrm{~cm}$ provides the required crumbling of the soil at minimum energy consumption.
\end{abstract}

\section{Introduction}

The development of new tillage technologies and the improvement of machinery to prepare crops, including gourds, is an urgent task in agriculture [1-23]. The problems of developing improved tillage technologies and tillage machines are considered in many scientific papers [24-27]. Research on the development of tillage machines and machines for preparing soil for sowing crops, including gourds, and the study of the interaction of working bodies with soil were carried out by F.Mamatov [1-23], B.Mirzaev [4-12], [14-21], [28-29], U.Umurzakov [4, 19], N.Aldoshin [3], [10-11], I.Ismoilov [3], [10-11], D.Chuyanov [5, 27], U.Kodirov [6, 24], H.Ravshanov [4-5], [6, 20], [25-26], I.Ergashev [2, 6, 12, 23, 30], P.Berdimuratov $[7,14]$ and others. These studies do not substantiate the placement of paraplow-type deep losers.

The aim of the study is to justify the placement of subsoilers on the machine to prepare the soil for sowing gourds.

\section{Methods}

The basic principles and methods of classical mechanics, mathematical analysis, and statistics were used in this study.

At the Karshi Institute of Engineering and Economics, the authors developed a

*Corresponding author: xfayzullayev77@mail.ru 
combined machine for preparing the soil for sowing gourds under a closed tunnel-type film (Figure 1). The machine is equipped with paraplough-type subsoilers. The subsoilers are equipped with loosening elements, which contribute to intensive loosening of the soil. The quality of loosening depends on the longitudinal distance between the subsoilers and the type and parameters of the loosening plate.

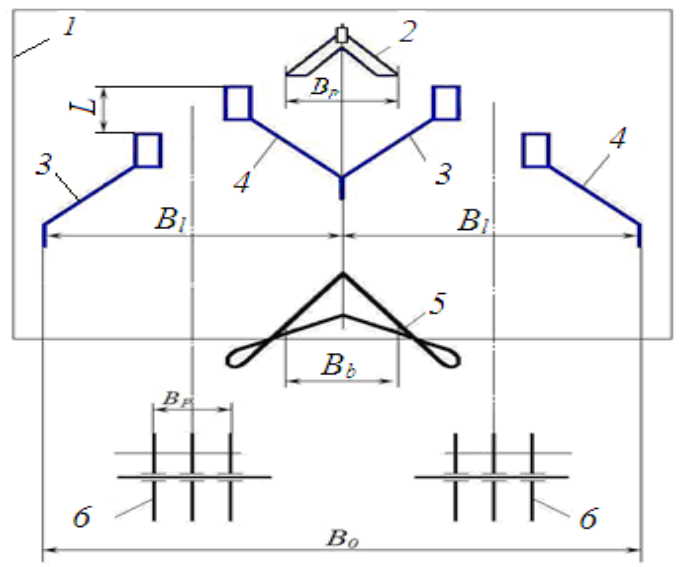

Fig. 1. Layout of work tools on the frame: 1 is frame; 2 is wing share; 3,4 are left and right deep loosening tools; 5 is furrow cutter; 6 is rotary ripper

When justifying the placement of tools, we assume that the ripper plates do not affect the longitudinal spacing of the subsoiler. To determine the longitudinal spacing of the subsoiler $\mathrm{L}$, consider the movement of the soil particles coming from the subsoiler bit. The part of the soil falling from the working surface of the excavator is equal to the geometric sum of the working velocity $V_{i}$ and the relative velocity of the part of the soil along the working surface is $V_{n}$. [31-32]. The motion of soil particles falling from a working body has been studied by some scientists based on the laws of theoretical mechanics [32, 34-35].

According to the scheme shown in fig.2, we determine the absolute velocity $V_{a}$ of soil fragments $V_{a}$, the projections of this velocity on the $X$ and $Z$ axes, and the time $t_{1}$ of the soil fragment along the $Z$-axis using the following formulas based on theoretical mechanical laws and previous research [31-32].

$$
\begin{gathered}
V_{a}=V_{i} \frac{\sin \alpha_{i}}{\cos \varphi} \\
V_{a x}=V_{i} \frac{\sin \alpha_{i}}{\cos \varphi} \sin \left(\alpha_{i}+\varphi\right) ; V_{a z}=V_{i} \frac{\sin \alpha_{i}}{\cos \varphi} \cos \left(\alpha_{i}+\varphi\right) . \\
t_{1}=\frac{V_{a z}}{g}=\frac{V_{i} \sin \alpha_{i} \cos \left(\alpha_{i}+\varphi\right)}{g \cos \varphi}
\end{gathered}
$$

where $\alpha_{i}$ is the angle of entry of the bit into the soil, degree; $\varphi$ is angle of internal friction of the soil, degree; $g$ is acceleration of gravity, $\mathrm{m} / \mathrm{s}^{2} ; V_{i}$ is the forward speed of the unit movement, $\mathrm{m} / \mathrm{s}$. 


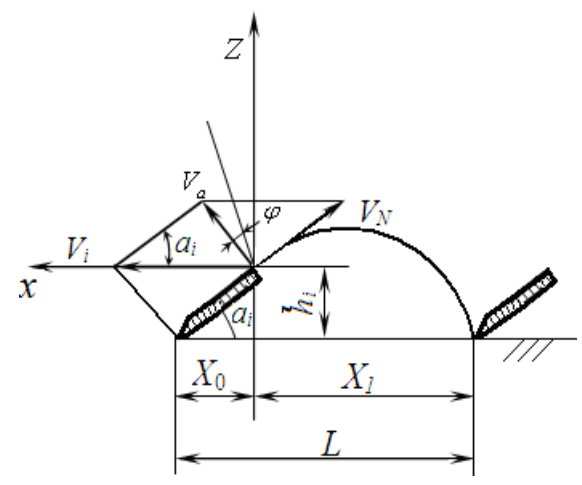

Fig. 2. Scheme for substantiating the minimum longitudinal distance between the pits

The distance of the soil fragments rise from the bottom of the layer treated by the scan is determined by the following formula [31-35].

$$
H=V \frac{\sin \alpha_{i}}{\cos \varphi} \cos \left(\alpha_{i}+\varphi\right) t_{1}-\frac{1}{2} g t_{1}^{2}+h
$$

$h_{i}$ is the height of the rise along the working surface of the soil screed, m. The time it takes for the piece of soil from the scaffold to fall back to the bottom of the scaffolding layer

$$
t_{2}=\sqrt{\frac{2 H}{g}} .
$$

Considering the above, the pieces of soil falling from the softener shaft fall to the following distance

$$
X_{1}=V_{i} \frac{\sin \alpha_{i}}{\cos \varphi} \sin \left(\alpha_{i}+\varphi\right)\left(t_{1}+t_{2}\right)
$$

According to fig.2, the minimum distance between the scanners of the sinkers

$$
L \geq X_{1}+l_{i} \cos \alpha_{i}
$$

Given the expressions (3) - (8), we obtain the following final expression

$$
\begin{aligned}
& L \geq \frac{V_{i}}{g \cos \phi}\left[1-\frac{\sin \alpha_{i}}{\cos \phi} \sin \left(\alpha_{i}+\phi\right)\right] \times\left\{V_{i} \sin \alpha_{i} \cos \left(\alpha_{i}+\phi\right)+\right. \\
& \left.+\sqrt{V_{i}^{2} \sin ^{2} \alpha_{i} \cos ^{2}\left(\alpha_{i}+\phi\right)+2 g h_{i} \cos ^{2} \phi}\right\}+l_{i} \cos \alpha_{i} .
\end{aligned}
$$

$h_{i}=0.054 \mathrm{~m}, a_{i}=20^{\circ}, p_{h}=30^{\circ}, g=9.81 \mathrm{~m} / \mathrm{s}^{2}$ and $l_{i}=0.15 \mathrm{~m}, V=2.5 \mathrm{~m} / \mathrm{s}$ at values $(8)$ the minimum longitudinal distance between the pits $L \geq 0.444 \mathrm{~m}$. 


\section{Results and Discussion}

Experimental studies investigated the effect of the type of ripping plates and the operating speed on the agrotechnical and energy performance of the machine. A laboratory unit was constructed for the experimental studies (Figure 3). The subsoilers were mounted on the frame with special brackets.

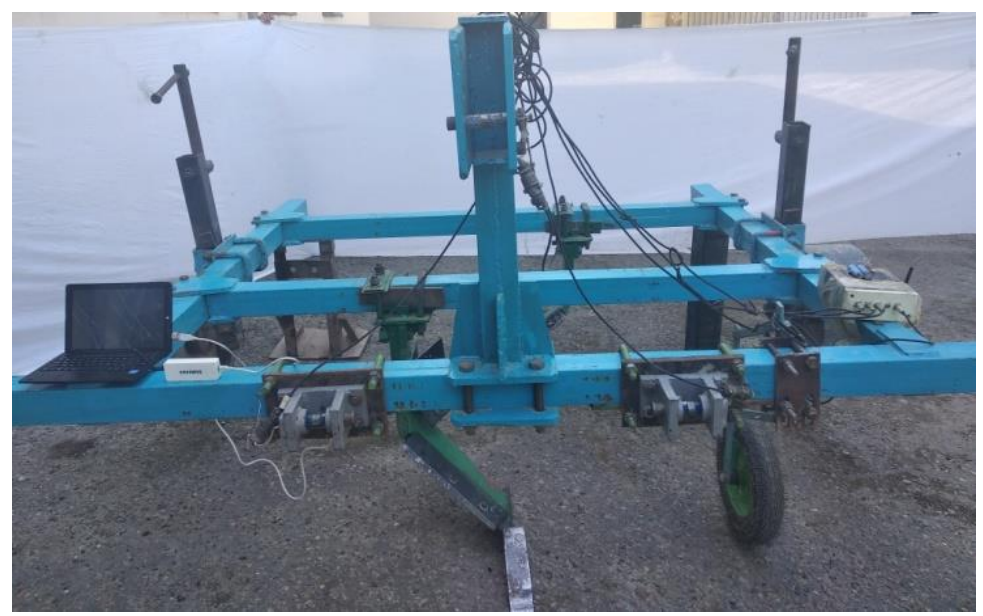

Fig. 3. General view of the laboratory-field device

To study the influence of ripper type and parameters on the traction resistance of deep ripper and ripping quality, right- and left-handed deep rippers and five types of ripping plates were made (Fig. 4 and 5).

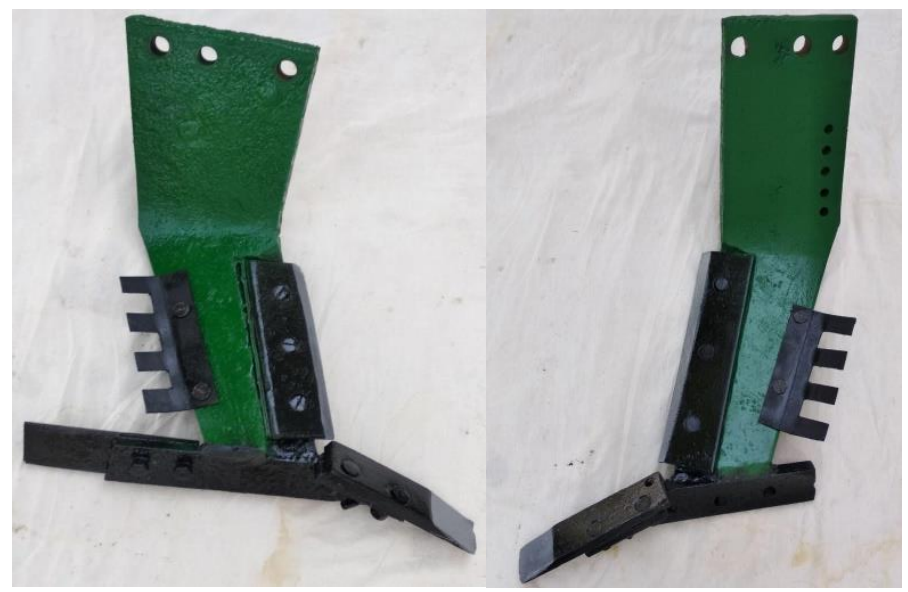

Fig. 4. Pits: 1 is working body bent to the right; 2 is left bent working body

The following types of plates have been produced: 1 is rectangle; 2 is trapezoidal; 3 is threaded; 4 is plate-shaped, and 5 is rectangular with softeners on the surface.

Based on earlier research [33], the length and height of the plates are assumed to be 12 $\mathrm{cm}$ and $20 \mathrm{~cm}$, respectively (Figure 5). The distance between bars and plates is assumed to be $3 \mathrm{~cm}$, the width of each plate is $2.75 \mathrm{~cm}$, and the length of the bar is $7 \mathrm{~cm}$. 


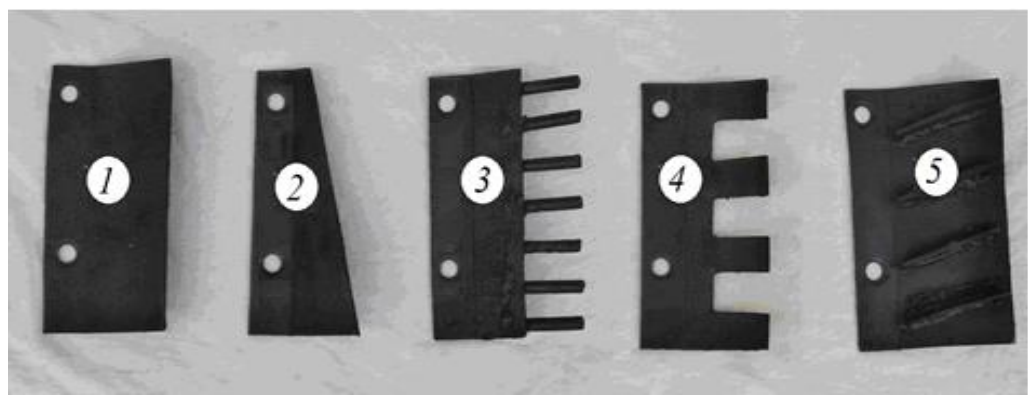

Fig. 5. Types of sink softener plates: 1 is rectangle; 2 is trapezoidal; 3 is threaded; 4 is plate; 5 is rectangular with softeners mounted on the surface.

The experiments were carried out at speeds of 6,25 and $7,6 \mathrm{~km} / \mathrm{h}$, and the depth of processing of the sinker was $25-33 \mathrm{~cm}$.

Table 1. The effect of the type of plate on the agrotechnical and energy performance of the device (at a speed of $6.25 \mathrm{~km} / \mathrm{h}$ and a processing depth of $33 \mathrm{~cm}$ )

\begin{tabular}{|c|c|c|c|c|}
\hline The type of plate & $\begin{array}{c}\text { Actual } \\
\text { processing } \\
\text { depth, cm }\end{array}$ & $\begin{array}{c}\text { Height of } \\
\text { ridges on field } \\
\text { surface, cm }\end{array}$ & $\begin{array}{c}\text { The degree of } \\
\text { crushing by the } \\
\text { amount of } \\
\text { fractions smaller } \\
\text { than } 50 \mathrm{~mm}, \%\end{array}$ & $\begin{array}{c}\text { Gravity } \\
\text { resistance of } \\
\text { the working } \\
\text { body, } \mathrm{kN}\end{array}$ \\
\hline Rectangle & 32.6 & 4.7 & 88.4 & 3.83 \\
\hline Trapezoidal & 32.8 & 3.8 & 88.4 & 3.77 \\
\hline Threaded & 32.7 & 2.7 & 88.6 & 3.41 \\
\hline Plate & 32.8 & 2.9 & 89.9 & 3.38 \\
\hline The surface is soft & 32.9 & 3.2 & 88.5 & 3.87 \\
\hline
\end{tabular}

The results of experiments to study the effect of the type of plates on the agrotechnical and energy performance of the device are given in Table 1.

The data presented show that the degree of soil erosion under the influence of all types of plates was at the required level.

The working height of the working bodies on the field surface is 2.0, respectively, to the height of the ridges and plates; $1.1 ; 0.5$ and 1.8 ; 0.9 ; Was $0.3 \mathrm{~cm}$ larger. This is mainly because the soil fragments rise upwards under the influence of rectangular, trapezoidal, and rectangular plates with softeners mounted on the surface. In grooved and plate softeners, the soil fragments are partially separated, which reduces the soil uplift.

Gravity resistance of threaded and plate softeners (Figure 5, note: trapezoidal and rectangular plates with softeners mounted on the surface are not shown in Figure 6 because they are close to the tensile resistance of rectangular plates) Rectangular, trapezoidal and rectangular softeners $8.4-9.3 \%$ less.

From the data in Figure 6, it can be seen that the type of plate has a significant effect on the gravity resistance of the sink. As the speed increases, the tensile resistance of the rectangular flat plate working body increases sharply, while the tensile resistance of the working bodies of the crank and plate softening element increases relatively less. The tensile strength of a rectangular flat-plate softener with a sloping handle is $6.4-8.7 \%$ greater than the tensile resistance of a hinged and plate-shaped softener at 6.25 and $8.8 \mathrm{~km} / \mathrm{h}$, respectively. 


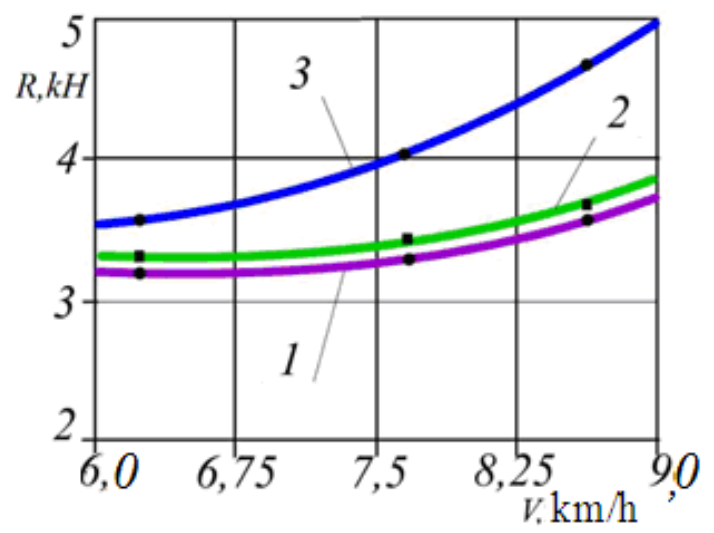

Fig 6. Variation of the resistance of the sinker to gravity depending on the speed: 1 is threaded; 2 is plate-shaped; 3 is rectangular plane

Therefore, according to the results of experimental studies, it is advisable to use threaded and plate softeners with a length of $12 \mathrm{~cm}$ and a height of $20 \mathrm{~cm}$ as an additional softening element in sinkers.

\section{Conclusions}

1. The arrangement of the left and right inclined subsoilers of the combination machine in pairs with their working surfaces facing each other and offset to each other in the longitudinal plane ensures the required quality of work with minimum energy consumption.

2. The use of a $12 \mathrm{~cm}$ long and $20 \mathrm{~cm}$ high subsoiler in the deep loosener as a rod and plate provides the required crumbling of the soil with minimum energy expenditure.

\section{References}

1. Mamatov, F.M., Eshdavlatov, E., Suyunov, A. The Shape of the Mixing Chamber of the Continuous Mixer // Jour of Adv Research in Dynamical \& Control Systems, Vol. 12, 07-Special Issue, DOI: 10.5373/JARDCS/V12SP7/20202318 ISSN 1943-023X. (2020).

2. Mamatov, F., Ergashev, I., Ochilov, S., Pardaev, X. Traction Resistance of Soil Submersibility Type "Paraplau" // Jour of Adv Research in Dynamical \& Control Systems, Vol.12, 07-Special Issue, DOI: 10.5373/JARDCS/V12SP7/20202336 ISSN1943-023X.

3. Aldoshin, N., Mamatov, F., Ismailov, I., Ergashov, G. Development of combined tillage tool for melon cultivation // 19th international scientific conference engineering for rural development Proceedings, Jelgava, 20.-22.05.2020. Volume 19. ISSN 16915976. DOI:10.22616/ERDev. 19.TF175. (2020).

4. Umurzakov, U., Mirzaev, B., Mamatov, F., Ravshanov, H., Kurbonov, S. A rationale of broach-plow's parameters of the ridge-stepped ploughing of slopes // XII International Scientific Conference on Agricultural Machinery Industry IOP Conf. Series: Earth and Environmental Science 403012163 IOP Publishing doi:10.1088/1755-1315/403/1/012163. (2019).

5. Mirzaev, B., Mamatov, F., Chuyanov, D., Ravshanov, X., Shodmonov, G., Tavashov, R and Fayzullayev, X. Combined machine for preparing soil for cropping of melons and gourds // XII International Scientific Conference on 
Agricultural Machinery Industry. doi.org/10.1088/1755-1315/403/1/012158.

6. Mirzaev, B., Mamatov, F., Ergashev, I., Ravshanov, H., Mirzaxodjaev, Sh., Kurbanov, Sh., Kodirov, U and Ergashev, G. Effect of fragmentation and pacing at spot ploughing on dry soils // E3S Web of Conferences 97. doi.org/10.1051/e3sconf/201913501065.

7. Mamatov, F., Mirzaev, B., Shoumarova, M., Berdimuratov, P., Khodzhaev, D. Comb former parameters for a cotton seeder// International Journal of Engineering and Advanced Technology (IJEAT) Volume-9 Issue1 October/ DOI: 10.35940/ijeat.A2932.109119.

8. Mamatov, F., Mirzaev, B., Batirov, Z., Toshtemirov, S., Tursunov, O., Bobojonov, L. Justification of machine parameters for ridge forming with simultaneous application of fertilizers // CONMECHYDRO - 2020 IOP Conf. Series: Materials Science and Engineering 883012165 IOP Publishing. doi:10.1088/1757-899X/883/1/012165. (2020).

9. Mirzaev, B., Mamatov, F., Avazov, I., Mardonov, S. Technologies and technical means for anti-erosion differentiated soil treatment system // E3S Web of Conferences. doi.org/10.1051/e3sconf/20199705036.

10. Aldoshin, N., Didmanidze, O., Mirzayev, B., Mamatov, F. Harvesting of mixed crops by axial rotary combines // Proceeding of $7^{\text {th }}$ International Conference on Trends in Agricultural Engineering 2019. $17^{\text {th }}-20^{\text {th }}$ September Prague, Czech Republic. - pp.2026. (2019).

11. Mirzaev, B., Mamatov, F., Aldoshin, N and Amonov, M. Anti-erosion two-stage tillage by ripper// Proceeding of 7th International Conference on Trends in Agricultural Engineering 17th-20th. September Prague, Czech Republic. - pp.391396. (2019)

12. Mirzaev, B., Mamatov, F., Ergashev, I., Islomov, Yo., Toshtemirov, B., Tursunov O. Restoring degraded rangelands in Uzbekistan // Procedia Environmental Science, Engineering and Management № 6. - pp 395-404. (2019).

13. Uzakov, Z.U., Mamatov, F.M., Begulov, O. Implementation of object-oriented Programming technology in the one-dimensional oil displacement problem // International Conference on information Science and Communications Technologies: ICISCT. Tashkent, Uzbekistan. INSPEC Accession Number: 19412491. DOI: 10.1109/ICISCT47635.(2019).

14. Mamatov, F., Mirzaev, B., Berdimuratov, P., Turkmenov, Kh., Muratov, L., Eshchanova, G. The stability stroke of cotton seeder moulder // CONMECHYDRO 2020. IOP Conf. Series: Materials Science and Engineering 883 (2020) 012145 IOP Publishing. doi:10.1088/1757-899X/883/1/012145.

15. Mamatov, F., Mirzaev, B., Tursunov, O. A Justification of Broach-Plow's Parameters of the Ridge-Stepped Ploughing // E3S Web of Conferences 97, 05035 (2019). doi.org/10.1051/e3sconf/20199705035.

16. Ahmedov, B.J., Mirzaev, B.S.,Mamatov, F.M., Khodzhaev, D.A., Julliev, M.K. Integrating of gis and gps for ionospheric perturbations in d- And f-layers using vlf receiver // InterCarto, InterGIS 26, - c. 547-560. DOI: 10.35595/2414-9179-2020-126-547-560.

17. Mamatov, F., Mirzaev, B., Tursunov, O., Ochilov, S and Chorieva, D. Relief, physicomechanical and technological properties of soil in the cotton growing area // ICECAE 2020. IOP Conf. Series: Earth and Environmental Science 614012169. IOP Publishing. doi:10.1088/1755-1315/614/1/012169. (2020).

18. Shamsutdinov, Z., Ubaydullaev, Sh., Shamsutdinov, N., Mirzaev, B., Mamatov, F., and Chorshabiyev, N. The concept of the phytogenic field: theory, research experience and practical significance // ICECAE 2020. IOP Conf. Series: Earth and 
Environmental Science 614012164. IOP Publishing. doi:10.1088/17551315/614/1/012164. (2020).

19. Umurzakov, U., Mamatov, F., Aldoshin, N., and Mirzaev, B. Exploration of tillage technologies in the Republic of Uzbekistan // ICECAE 2020 IOP Conf. Series: Earth and Environmental Science 614(2020) 012168. IOP Publishing. doi:10.1088/17551315/614/1/012168.

20. Mamatov, F., Aldoshin, N., Mirzaev, B., Ravshanov, H., Kurbanov, Sh and Rashidov, N. Development of a frontal plow for smooth, furless plowing with cutoffs // IPICSE 2020. IOP Conf. Series: Materials Science and Engineering 1030 (2021) 012135 IOP Publishing. doi:10.1088/1757-899X/1030/1/012135.

21. Mamatov, F., Mirzaev, B., Mirzahodzhaev, Sh., Uzakov, Z and Choriyeva, D. Development of a front plow with active and passive working bodies // IPICSE 2020. IOP Conf. Series: Materials Science and Engineering 1030 012164. IOP Publishing. doi:10.1088/1757-899X/1030/1/012164. (2021).

22. Mamato, F.M., Eshdavlatov, E., Suyuno, A. Continuous Feed Mixer Performance //Journal of Advanced Research in Dynamical and Control Systems (JARDCS). Volume-12, 07-Spesia1 Issue, DOI: 10.5373/JARDCS/V12SP7/20202343. ISSN 1943-023X. (2020).

23. Mamatov, F., Ergashev, I., Mirzaev, B., Pardaev, X, Chorieva, D. Research of the Penetration Process of the Frontal Plow // 2nd Bukittinggi International Conference on Education (BICED) 2020. Journal of Physics: Conference Series 1779 012002. IOP Publishing. doi:10.1088/1742-6596/1779/1/012002. (2021).

24. Kodirov, U., Aldoshin, N., Ubaydullayev, Sh., Sharipov, E., Muqimov, Z and Tulaganov, B. The soil preparation machine for seeding potatoes on comb // CONMECHYDRO - 2020 IOP Conf. Series: Materials Science and Engineering 883(2020).

25. Ravshanov, Kh., Fayzullaev, Kh., Ismoilov, I., Irgashev, D., Mamatov, S. The machine for the preparation of the soil in sowing of plow crops under film // CONMECHYDRO - 2020 IOP Conf. Series: Materials Science and Engineering 883(2020).

26. Ravshanov, H, Babajanov, L, Kuziev, Sh, Rashidov, N, Kurbanov, Sh. Plough hitch parameters for smooth tails// CONMECHYDRO - 2020 IOP Conf. Series: Materials Science and Engineering 883(2020).

27. Chuyanov, D., Shodmonov, G.,Avazov, I., Rashidov, N, Ochilov, S. Soil preparation machine parameters for the cultivation of cucurbitaceous crops // CONMECHYDRO - 2020 IOP Conf. Series: Materials Science and Engineering 883(2020).

28. Mamatov F.M., Mirzaev B.S., Avazov I.Zh.. Agrotehnicheskie osnovy sozdanija protivojerozionnyh vlagosberegajushhih tehnicheskih sredstv obrabotki pochvy $\mathrm{v}$ uslovijah Uzbekistana // - Prirodoobustrojstvo, [In Russian]. (2014).

29. Mamatov F.M., Mirzaev B.S. Erosion preventive technology of crested ladder-shaped tillage and plow design // European Applied Sciences. Stuttgart (Germany), (2014).

30. Lobachevskij Ja.P., Mamatov F., Jergashev I.T. Frontal'nyj plug dlja hlopkovodstva // - Hlopok, № 6. -35-37 str. [In Russian]. (1991).

31. Bat' M.I., Dzhanelidze G.Ju., Kel'zon A.S. Teoreticheskaja mehanika v primerah i zadachah. - M.: «Nauka». - 1984, - 504 s. [In Russian].

32. Abdulhaev H. Obosnovanie parametrov orudija dlja obrabotki grebnej: Diss. ... dokt. fil. tehn. nauk. - Tashkent, (2019).

33. Mironov G.I. Na sklonah lesostepi Ukrainy // Zemledelie.- Moskva, (1984).

34. Fayzullayev, Kh, Mamatov, S, Radjabov, M, Sharipov, Sh, Tavashov, R and Nurmanova, M. The quality of loosening the soil with subsoilers of the combined machine // IPICSE 2020. IOP Conf. Series: Materials Science and 
Engineering 1030 012171.IOP Publishing. doi:10.1088/1757-899X/1030/1/012171. 2021).

35. Temirov, I, Ravshanov, Kh, Fayzullaev, Kh, Ubaydullaev, Sh and Kodirov, U. Development of a machine for preparing the soil for sowing melons under the film // IPICSE 2020. IOP Conf. Series: Materials Science and Engineering 1030 012169. IOP Publishing. doi:10.1088/1757-899X/1030/1/012169. (2021). 